Aziz Nacib Ab'Sáber, doutor em ciências, ex-diretor do Instituto de Geografia da USP, ex-presidente do Conselho de Defesa do

Patrimônio Histórico Artístico e Arqueológico do Estado de São Paulo - CONDEPHAAT.

Especialista em geomorfologia do Brasil, geografia tropical, planejamento regional e gerenciamento do meio ambiente.

\title{
O domínio dos cerrados: introdução ao conhecimento
}

Todo pesquisador que na juventude cometeu a audácia de estudar uma região de seu país - de grande ou pequeno espaço, de longa ou curta história - aspira retornar muitos anos depois, a fim de reexaminar os fatos observados e revisar a nova conjuntura, criada por forças da dinâmica social e pela atuação de fatores até certo ponto imponderáveis. Para um geógrafo, voltar a uma região do grande interior brasileiro, é um ato de revisão das paisagens e espaços, a nível do físico, ecológico e social. Mas também a oportunidade de se questionar a si próprio, em termos de mudança de ótica de observação e do modo de perceber os sistemas de relações entre grupos humanos e meios geográficos em mudança.

Temos a impressão que retornar a regiões pesquisadas no passado, em paises de velhas e quase imutáveis estruturas agrárias, pode ser uma tarefa até certo ponto decepcionante. Pensamos, sobretudo, em alguns casos da rígida estrutura social e econômica da campanha francesa e de sua rede de velhas aldeias, resistentes a quase toda modernização e transformações. No caso do Brasil, porém, em áreas onde o arcaísmo cedeu lugar a uma modernização incompleta, a tarefa de retornar para reanalizar é, quase sempre, um projeto fadado a ser gratificante.

Em nosso país, no decorrer de três décadas, algumas regiões mudaram em quase tudo, incorporando padrões modernos que, muitas vezes, abafaram por substituição, velhas e arcaicas estruturas so- ciais e econômicas. Tais mudanças se ligaram, sobretudo, a implantações da novas infra-estruturas viárias e energéticas e a descoberta de impensadas vocações dos solos regionais para atividades agrárias rentáveis. Pensamos, explicitamente, no caso do centro-sul e sudoeste de Goiás e no exemplo da porção ocidental dos planaltos do Paraná, Santa Catarina e Rio Grande do Sul.

No caso de Goiás e Mato Grosso - tomados em seu conjunto - as modificações dependeram de transformações fundamentais na produtividade das terras de cerrados, ao par com uma extensiva modernização dos meios de transporte e circulação. Acima de tudo, porém, o desenvolvimento regional deveu-se a uma harmoniosa transformação acoplada do meio urbano e dos meios rurais, a serviço da produção de alimentos. No conjunto desses processos, certamente foi muito importante o conjunto de modificações na rede urbana do Brasil Central, forçadas pela implantação de Brasília. A revitalização da rede urbana atingiu todos os quadrantes regionais do domínio dos cerrados: o Triângulo Mineiro, através de Uberlândia e Uberaba e suas sub-redes urbanas; o sul de Mato Grosso, através de Campo Grande e Dourados; o sudoeste de Goiás, através de Rio Verde, Jataí e Bom Jesus; o centro de Goiás, por meio de Anápolis, Goiânia e Brasília; e a rede urbana em reestruturação de Mato Grosso do Norte, através de relações leste-oeste e sul-norte, na direção de Rondônia e a Amazônia. O próprio extremo norte de 
Goiás, dotados de solos menos férteis do que a metade sul, transmudou-se por meio de uma pequena rede de centros urbanos de apoio, ao ensejo da construção e consolidação da rodovia Belém-Brasília, que é mais propriamente uma ligação Anápolis-Belém do Pará.

Não nos envolveremos com considerações sobre regiões que evoluíram pouco apesar do advento de infra-estrutura viárias relativamente modernas e a despeito mesmo de injeções de capitais financeiros, que não tiveram força para uma redistribuição justa a serviço do homem e da sociedade regional, vista como um todo.

Preocupados em fixar idéias sobre o nível de evolução recente do Brasil Central dentro de nossas possibilidades de geomorfologistas - queremos contribuir para uma revisão da gênese das paisagens e dos espaços geoecológicos, de uma região que está no meio do processo motor de modernização e de desenvolvimento do país. Acreditamos que uma revisão das bases físicas, que sustentaram a revitalização econômico-social da região, possa ser útil ao conhecimento científico e, quiçá, para o esforço de preservação dos fluxos vivos da natureza regional.

O domínio dos chapadões recobertos por cerrados e penetrados por florestas galerias - de diversas composições - constitui-se em um espaço físico ecológico e biótico, de primeira ordem de grandeza, possuindo de 1,7 a 1,9 milhões de quilômetros quadrados de extensão. O polígono dos cerrados centrais brasileiros, muito embora tenha uma posição zonal em relação ao grande conjunto das savanas e cerrados da África Austral e da América Tropical, a nível dos espaços fisiográficos e ecológicos brasileiros, é apenas mais um dos grandes poligonos irregulares que formam o mosaico paisagístico do país. No Brasil, sem qualquer dúvida, o caráter longitudinal e o grau de interiorização das matas atlânticas quebrou a possibilidade de uma distribuição leste-oeste marcada para o domínio dos cerrados, representante sul-americano da grande zona das savanas. Por outro lado, a composição florística dos tipos de vegetaçaõ da área nuclear dos cerrados - constituído por padrões regionais de cerrados e cerradões - é muito diversa das verdadeiras savanas, existentes em território africano.

$\mathrm{Na}$ África predomina um arranjo transicional gradual para os diversos tipos de savanas, desde a borda das grandes matas da Guiné até as lindes das estepes subdesérticas e desérticas, pré-saharianas e pré-kalaarianas. No Brasil, cerrados e cerradões se repetem por toda a parte no interior e margens da área nuclear dos domínios morfoclimáticos regionais. As variações florísticas dizem respeito muito mais aos tipos de florestas galerias do que propria- mente aos padrões de cerrados e cerradões dos interflúvios.

Nas áreas onde ocorriam cerradões - hoje muito degradados por diferentes tipos de ações antrópicas - existiam verdadeiras florestas baixas e de troncos relativamente finos, por processos naturais de adensamento de velhos stocks florísticos de cerrados quaternários e terciários. Os campestres ilhados no meio de grandes extensões de cerrados e cerradões, não passam de enclaves de campos tropicais e, portanto, de savanas brasileiras (noroeste de Mato Grosso, sudoeste de Goiás, faixas de campos limpos de áreas dissecadas em cabeceiras de subbacias hidrográficas, serranias quartzíticas, situadas ao norte de Brasília) e de pradarias mistas subtropicais de planalto (campo de vacaria, em Mato Grosso do Sul).

O domínio dos cerrados, em sua região nuclear, ocupa predominantemente maciços planaltos de estrutura complexa, dotados de superfícies aplainadas de cimeira, e um conjunto significativo de planaltos sedimentares compartimentados, situados em níveis que variam entre 300 e 1.700 metros de altitude. As formas de terrenos são, grosso modo, similares tanto nas áreas de terrenos cristalinos aplainados quanto nas áreas sedimentares sobreelevadas e transformadas em planaltos típicos. No detalhe, entrementes, as feições morfológicas são muito mais diversificadas, fato bem testemunhado pelo caráter compósito dos padrões de drenagem das sub-bacias hidrográficas, ainda que, em conjunto, chapadões sedimentares e chapadões de estrutura complexa e de velhos terrenos, tenham o mesmo comportamento na estruturação de paisagens físicas e ecológicas no domínio dos cerrados. No caso particular do domínio dos cerrados, não existe a necessidade de se pressupor a existência de um subdomínio de formas peculiares às áreas sedimentares, por oposição à maior tipicidade dos terrenos cristalinos, como acontece em todos os outros domínios morfoclimáticos brasileiros.

A nível da escala paisagística observável diretamente pelo homem, o domínio dos cerrados apresenta os cerrados e cerradões predominantemente nos interflúvios e vertentes suaves dos diferentes tipos de planaltos regionais. Faixas de campos limpos ou campestres sublinham as áreas de cristas quartzíticas e xistos malpedogenetizados dos bordos de chapadões onde nascem bacias de captação de pequenas torrentes dotadas de forte capacidade de dissecação (centro-sul de Goiás). Por sua vez, as florestas galerias permanecem amarradas rigidamente ao fundo aluvial dos vales de porte médio a grande. Os sulcos das cabeceiras dendritificadas das sub-bacias hidrográficas possuem apenas uma vegetação ciliar, disposta linearmente, em sistema de frágil implan- 
tação. As florestas galerias verdadeiras, às vezes ocupam apenas os diques marginais do centro das planícies de inundação, em forma de corredor contínuo de matas; outras vezes, quando o fundo aluvial é mais homogêneo e alongado, ocupam toda a calha aluvial, sob a forma de serpenteantes corredores florestais.

Não raro, em alguns setores, estendem-se continuadamente pelo setor aluvial central das planícies, deixando lugar para corredores herbáceos nos dois bordos da galeria florestal, arranjo fitogeográfico reconhecido pelo nome popular de veredas. Tal situação, muito comum nos setores de cerrados que envolvem o domínio das caatingas, corresponde a casos em que predominam sedimentos arenosos nos bordos das planícies de inundação. Por esta razão as veredas se comportam como corredores de formações herbáceas rasas, no fundo lateral das planícies de inundação onde existem résteas subatuais de areias malpedogenetizadas (regossolos planos). As veredas, a nosso ver, estão para os lados das matas galerias no domínio dos cerrados, tal como os chamados ariscos estão para as estreitas galerias de diques marginais de rios intermitentes sazonários, no interior do domínio das caatingas.

Do mesmo modo, as campinas de várzeas na Amazônia, são veredas encharcadas de areias brancas situadas à margem de florestas galerias de diques marginais, no centro de antigas faixas de areias geradas em condições climáticas rústicas, constituindo outra modalidade de ecossistemas diversificados, de complexa origem paleoclimática e fluvial. Apenas a título de informação, queremos lembrar que a região protótipo para o estudo dessas faixas de areias brancas, situadas em várzeas do reverso de diques marginais florestados, similares aos casos de veredas e ariscos, é o Vale do Moju, a leste de Tucuruí (Ab'Saber, 1982), em plena Amazônia Oriental. Todos esses padrões anômalos de setores de planícies de inundação deveria ficar totalmente à margem de cogitação dos projetos ditos Pró-Várzea, para evitar gastos e expectativas inúteis, em função das peculiaridades desses ecossistemas, que não têm vocação agrícola identificável. Recado válido para tecnocratas e especuladores, de todos os naipes.

O domínio dos cerrados possui drenagens perenes para os cursos d'água principais e secundários, envolvendo, porém, o desaparecimento temporário dos caminhos d'água de menor ordem de grandeza, por ocasião do período seco do meio do ano. Desta forma, coexiste uma perenidade geral para a drenagem dos cerrados, com um efeito descontínuo de intermitência sazonal para os caminhos d'água das vertentes e interflúvios, ao par com uma atenuação dos fluxos d'água nos canais de escoamento das pequenas sub-bacias de posição interfluvial. 0 ritmo marcante da tropicalidade regional, com estações muito chuvosas alternadas com estações secas incluindo um total de precipitações anuais de três a quatro vezes aquele ocorrente no domínio das caatingas - implica em uma preservação extensiva dos padrões de perenidade dos cursos d'água regionais. Mesmo nos canais de escoamento laterais aos chapadões e de muita pequena extensão, permanece uma espécie de linha de molhamento d'água subsuperficial, durante toda a estação seca de meio do ano. O lençol d'água sofre variações ao longo do ano, desde 1-1,5 metros até 3-4 metros no subsolo superficial dos cerrados, continuando, porém, tangente à superfície da topografia, alimentando as raízes da vegetação lenhosa dos cerrados.

A aparência xeromórfica de muitas espécies do cerrado é falsa; segundo Ferri (1963) tratar-se-ia de um pseudoxeromorfismo, fato que endossaria a hipótese de um escleromorfismo oligotrófico (Arens, 1963). As plantas lenhosas dos campos cerrados seriam, portanto, uma flora de evolução integrada com as condições dos climas e solos dos trópicos úmidos, sujeitos a forte sazonaridade.

A natureza física e ecológica dos cerrados não apresenta maiores deficiências hídricas no solo subsuperficial, apresentando, entrementes, fortes deficiências de umidade do ar na prolongada estiagem do meio do ano. Para Arens (1963), "'a flora dos campos cerrados é exposta ao máximo de iluminação pelo clima, que se caracteriza por um número elevado de dias de céu descoberto e pela natureza da vegetação rala que produz sombra mínima". Situação que consideramos verdadeira sobretudo para o período de inverno seco, mas que é modificada em muito durante o verão chuvoso. Nesse sentido, há que estudar, com mais cuidado o comportamento da flora dos cerrados e dos cerradões, nos dois momentos estacionais tão contrastados.

Climaticamente, o domínio dos cerrados - em sua área nuclear - comporta de cinco a seis meses secos, opondo-se a seis ou sete meses relativamente chuvosos. As temperaturas médias anuais variam de amplitude, de um mínimo de 20-22; até um máximo de 24-26, levando-se em conta o espaço total dos cerrados desde o sul de Mato Grosso até ao Maranhão-Piáuí. Nenhum mês possui temperatura média inferior 18$^{\circ}$ (Nimer, 1977). Entretanto, a umidade do ar atinge níveis muito baixos no inverno seco $(38-40 \%)$, e níveis muito elevados no verão chuvoso $(95-97 \%)$. Tal fato acentua a sazonaridade, que tem sido vista, sobretudo, em termos de alternância de estações chuvosas com estações secas. Entretanto, no inverno seco, a taxa de umidade do ar no domínio dos cerrados é tão baixa ou mais do que aquela do domínio das caatingas, na mesma época.

A combinação de fatos físicos, ecológicos e 
bióticos, que caracteriza o domínio dos cerrados, é, na aparência, de relativa homogeneidade, extensível a grandes espaços. A repetitividade das paisagens vegetais ligadas ao tema dos cerrados - cerrados, cerradões, campestres de diversos tipos contribui muito para esse caráter monótono desse grande conjunto paisagístico. Mesmo, entretanto, sob o ponto de vista exclusivamente morfológico, o domínio dos cerrados apresenta sutis diferenciações de padrões de paisagens, em função de fatores litológicos e estruturais.

- Predomínio da decomposição química, mais ou menos profunda, porém não totalmente generalizada no espaço, das rochas cristalinas, na fai$x a$ dos gnaisses e micaxistos. Atenuação da decomposição, em profundidade, das rochas quartzíticas e de xistos argilosos, expostos em grandes extensões. Alterações contidas de arenitos e siltitos e fraco aprofundamento da decomposição de afloramentos basálticos. Do que decorre a existência de "terra roxas de campo", velha expressão criada por fazendeiros paulistas e mato-grossenses.

- Predominância de latossolos, tanto para áreas sedimentares como para terrenos cristalinos ou cristalofilianos e eventuais exposições de basaltos. As áreas onde as crostas duras de laterita já foram eliminadas, ou nunca existiram, têm melhores condições a ofertar para atividades agrícolas, sob a condição de calagem de calcários ou de uso de adubos fosfatados. Em cima das espessas cangas de laterais fósseis - presumivelmente de idade oligocênica, em alguns altos interflúvios de chapadões somente sobrevivem mirrados substandards.

- Convexização em geral discreta, porém fortemente diferenciada de nível topográfico para nível topográfico, e de província geológica para província geológica. No Brasil Central, os altos chapadões destituídos de cangas e dominados por gnaisses e rochas metamórficas heterogêneas, têm a tendência para uma larga e bem-marcada convexização. Quartzitos e xistos resistentes, apresentam perfis irregulares de vertentes, com setores semi-escarpados ravinados. Cerrados e cerradões de maior biomassa recobriam os setores de convexização mais bemmarcada, enquanto que os setores quartzíticos possuíam coberturas herbáceas ralas, pontilhadas por raquíticas espécies dos cerrados. No sul de Mato Grosso, pradarias mistas interfluviais documentavam a presença de solos naturalmente mais ricos em nutrientes, envolvidos por faixas de cerrados de meia encosta e, mais abaixo, no fundo e vertente baixas dos vales, por florestas galerias ampliadas. Nos campos das vertentes a oeste de Barbacena (MG), os campestres se limitam aos altos dos morros em áreas de chãos pedregosos maltamponados, en- quanto que uma faixa de cerrados, grosso modo, disposta em curva de nível, separam as matas secas dos vales em relação aos pobres campestres de cimeira e altas vertentes. Em muitos setores sedimentares, ou em áreas cristalinas rebaixadas, dotadas de solos relativamente rasos, existem grandes extensões de cerrados, transformados em pastos sujos, com vegetação rala e esparsa (cerradinhos). Os verdadeiros cerradões quase sempre ocorriam em setores de chapadões com vertentes convexizadas e melhores padrões de solos.

- Predominam por grandes espaços no domínio dos cerrados, padrões de drenagem variando de subparalelo e ligeiramente dendrítico. Trata-se de área que possui, via de regra, os menores índices de densidade de drenagem, fazendo grande contraste com os padrões ocorrentes nas áreas tropicais úmidas. Padrões compósitos de drenagem podem ocorrer em áreas de predominância de estruturas dobradas aplainadas, em que as faixas litológicas tornamse muito desiguais em extensão e em forma de participação na compartimentação da topografia. Nesses casos - muito comuns desde o sudoeste de $\mathrm{Mi}$ nas Gerais até as proximidades de Brasília - coexistem padrões espaçados, subparalelos e ligeiramente dendríticos, com padrões mais densos pertencentes a bacias de captação de drenagens, em setores semi-escarpados, ravinados e dominados por campestres de solos muito pobres.

\section{Compartimentos de relevo na área nuclear dos cerrados}

A imagem, geralmente feita, de que a área dos cerrados seria constituída apenas por enormes chapadões, situados na posição de divisores entre a drenagem do Prata e do Amazonas, é somente pró-parte verdadeira. Certamente se trata do domínio morfoclimático brasileiro onde ocorre a maior massissividade, extensividade e homogeneidade relativa de formas topográficas planálticas do Brasil intertropical. Planaltos sedimentares cedem lugar, quase sem solução de continuidade, para planaltos de estruturas mais complexa, nivelados por velhos aplainamentos de cimeira, formando o grande Planalto Central. Nunca será demais lembrar que o conjunto espacial do domínio dos cerrados, nos altiplanos centrais, representa mais ou menos a metade da área total do gigantesco conjunto de terras altas, de mediana altitude $(600-1.100 \mathrm{~m})$, designado por Planalto Brasileiro.

Comparado com as acidentadas e corrugadas terras do sudeste e leste do país, o Planalto Central efetivamente pode ser considerado uma vasta área de chapadões, revestidos por cerrados e penetrados 
por florestas galerias. Um "mar de chapadões", com cerrados, interpenetrado por florestas galerias, opondo-se a um "mar de morros" originalmente florestados. O próprio nordeste seco, com suas largas depressões interplanálticas e intermontanas - dominados por caatingas e drenagens intermitentes - , é muito mais compartimentado que o elevado e relativamente contínuo conjunto de terras altas do Brasil Central. Nesse sentido, uma diferença essencial marca esses dois domínios morfoclimáticos e fitogeográficos. Em sua área nuclear os cerrados ocupam os interflúvios de um extensíssimo planalto. No domínio das caatingas, a área nuclear situa-se predominantemente nas depressões interplanálticas, em posição totalmente oposta à dos cerrados.

Esse quadro, válido para observações de conjunto, na escala de "universos" paisagísticos regionais, pode sofrer, entretanto, algumas modificações significativas, quando transmudados para escalas mais próximas do sub-regional. No primeiro caso, conjuntos paisagísticos apreendidos na escala de mapas, e no segundo, paisagens regionais vistas na escala de cartas topográficas. Ou, mais tecnicamente, conjuntos espaciais de primeira ordem de grandeza (mais de um milhão de quilômetros de extensão), opondo-se a observações feitas na escala de relevos de terceira ordem de grandeza (10.000 a 100.000 quilômetros de extensão), segundo a classificação de Cailleux-Tricart (1955).

Para fins de uma compreensão mais detalhada da distribuição dos cerrados pelos compartimentos de relevo, mais significativos, do próprio Planalto Central, há que aprofundar a escala de tratamento geomorfológico até ao nível do entendimento da compartimentação topográfica de depressões interplanálticas e depressões denudacionais ditas periféricas. Mesmo porque parte da história da expansão das coberturas vegetais que deram origem ao continunn atual da área nuclear dos cerrados, fez-se pela expansão descendente dos tecidos ecológicos dos cerrados de altiplanos para algumas das depressões interplanálticas existentes no centro ou na periferia do antigo grande refúgio dos cerrados do Brasil Central. Muitas de tais depressões, até há poucos milênios, foram mais secos do que atualmente, ainda que um pouco menos quentes (13.000 - 18.000 anos). E, como se verá, tais setores interplanálticos, foram exatamente aqueles que tiveram maior sensibilidade relativa para as variações climáticas do Quaternário, ao longo de todo o Planalto Brasileiro (Ab'Saber, 1964, 1965). Daí, porque, tais áreas merecem tratamento especial em termos de setores que só recentemente - nos últimos dez milênios serviram de áreas para expansão e coalescência dos cerrados (e cerradões), anteriormente localizados apenas nas cimeiras dos chapadões centrais.
Dos refúgios de cerrados e cerradões, existentes na cimeira dos planaltos centrais, partiram as biomassas sob a forma de "manchas de óleo" coalescentes, as quais povoaram as depressões interplanálticas até então secas, situadas ao norte de Goiás, no Maranhão-Piauí, no Pediplano Cuiabano, no Médio Vale Superior do São Francisco, no Paraná, na depressão periférica paulista, nas colinas campestres de Roraima e do Amapá. Mais recentemente, dos cerrados de cimeiras e dos cerrados interplanálticos se expandiram cerrados e campestres para as depressões aluviais e pró-partes eólicas dos Llanos do Orenoco (Morales, 1979) e regiões similares, postadas na costa ou em compartimentos interiores da metade norte da América do Sul. Fica assim comprovado o grande arcaísmo da vegetação dos cerrados, intuído por diversos pesquisadores, em diferentes épocas e por diferentes roteiros de interpretação (Smith, 1885; Sampaio, 1934; Ab'Saber e Costa Júnior, 1957,1963). Houve uma geração arcaica de cerrados que deve ter remontado aos primeiros tempos do Terciário e que depois recuou para refúgios intermediários à medida que se abriram e se expandiram as depressões interplanálticas. Estas, por sua vez, receberiam uma segunda geração de cerrados vindos dos refúgios de cimeira, a qual disputou espaço com as caatingas e floras secas, por ocasião das flutuações climáticas do Pleistoceno. E, por fim, quando os climas úmidos passaram a predominar e as caatingas se circunscreveram praticamente ao nordeste semi-árido atual, algumas biomassas de cerrado se deslocaram para o nordeste da América do Sul, ocupando espaços dos campos de dunas e aluviões grosseiros, herdados máximo da semiaridez quartenária antiga (Pleistoceno Terminal), na depressão do Orenoco (Morales, 1979). Esta, a terceira e mais recente vogal de cerrados, reexpandida a partir dos refúgios existentes em colinas de depressões interplanálticas e intermontanas (Amapá, Grã-Sabana).

\section{Conjuntos topográficose condicionantes climáticos do domínio dos cerrados}

O Planalto Central tem o seu corpo territorial básico centrado em três unidades geomorfológicoestruturais, de grande extensão: o setor norte dos planaltos sedimentares (elou basálticos) da Bacia do Paraná, desfeitos em um relevo de cuestas concêntricas de frente externa, com altitudes variando entre 300 e 1.100 metros; o altiplano de rochas antigas e estruturas dobradas do centro de Goiás (altiplano de Brasília), com velhos aplainamentos hoje colocados na cimeira dos planaltos (série de superfícies) 
aplainadas de cimeira, remontantes ao Terciário Inferior, em termos de idade geomorfológica; e, os planaltos sedimentares cretácicos da Bacia do Urucuia, situados a nordeste de Minas Gerais e oeste da $\mathrm{Ba}$ hia, ladeados por duas depressões periféricas, muito bem pronunciadas (depressão periférica, do Médio Vale do São Francisco e depressão periférica do Paranã). E, por fim, setores descontínuos de depressões interplanálticas - geneticamente muito variados, do ponto de vista geomorfológico - circundam as terras altas sedimentares ou cristalinas, por todos os quadrantes, menos o sul e o sudoeste, na direção do Paraná, Paraguai e Argentina.

De certa forma, é essa rede de depressões interplanálticas, situadas a leste, nordeste, norte, noroeste e oeste do Planalto Central, que salienta o espaço geográfico principal do domínio dos cerrados, em sua área nuclear. Por outro lado, a maior parte desses extensos compartimentos deprimidos são áreas de contato entre stocks de vegetação pertencentes a diferentes províncias florísticas. Na depressão periférica paulista, na dependência de solos de diferentes fertilidades naturais, ocorrem matas e cerrados, em mosaico complexo. Na depressão do Médio Vale do São Francisco, ocorrem florestas e cerrados ao sul e caatingas ao norte. A oeste, na depressão do Pantanal, originada por uma combinação complexa de tectônica quebrável, eversão, aplainamentos neoterciários e recheio aluvial coalescente quaternário, ocorre o complicado contato entre a vegetação dos cerrados com as do Chaco Oriental e das palmáceas pré-amazônicas. Apenas para o norte, após as terminações acidentadas do altiplano de Brasília, e além dos refúgios de matas do chamado "Mato Grosso de Goiás" estende-se uma subárea dos cerrados, que atinge as proximidades do Pontal Araguaia-Tocantins, enquanto outro braço terminal de vegetacão típica do Planalto Central adentrase pelos chapadões do sul e centro do Maranhão, até os reversos dos planaltos empenados (tilted plateaus) da Bacia do Maranhão-Piauí. Já, além da escarpa terminal da Serra Grande do Ibiapaba, em pleno Ceará - em notáveis depressões interplanálticas - , inicia-se o domínio semi-árido dos "sertões se-

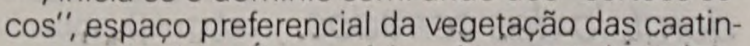
gas nordestinas. É nessa faixa, de contato brutalentre espaços fisiográficos e ecológicos, que se pode perceber melhor a posição preferencial dos cerrados e das caatingas nos diferentes compartimentos do relevo regional: os cerrados permanecem no interflúvio das chapadas, quer como massas vegetais contínuas, quer como refúgios (caso do Araripe Oriental); as caatingas amarram-se às depressões interplanálticas sertanejas, quentes e semi-áridas, dotadas de drenagens intermitentes e tecidos ecológicos próprios. A sazonaridade dos climas tropicais continua sob um só e mesmo regime; no entanto, o total de precipitações anuais é de, pelo menos, duas a cinco vezes maior nos altiplanos com cerrados do que nas depressões interplanálticas ou encostas de "serras secas". E, mesmo que ocorra um ano de verão mais chuvoso nas caatingas, o semestre seco continua sendo muito bem-pronunciado e malservido por águas.

Ainda que os enclaves de cerrados no domínio das caatingas estejam em regiões climáticas muito quentes e secas, é de se destacar o fato de que os cerrados, em sua área nuclear estão, e, sobretudo, estiveram, em áreas climáticas um pouco mais frescas do que aquela que impera no domínio das caatingas. Nesse sentido, os enclaves de cerrados primam por estar em condições bastante adversas do ponto de vista climático, já que eles ocorrem em setores tão diferentes quanto sejam o Amapá, o nordeste da Bahia (Ribeira do Pombal), os tabuleiros sublitorâneos do nordeste oriental, a região de São José dos Campos, no Médio Vale do Paraíba do Sul, a depressão periférica paulista, e as manchas de cerrados residuais de Jaguariaíva-Sengês e Campo Mourão, no nordeste e centro-norte do Estado de Paraná. No universo geoecológico do Brasil intertropical não existe comunidade biológica mais flexível e dotada de poder de sobrevivência em solos pobres do que os cerrados.

Na sua área "core", os cerrados se instalam há muito tempo através de espaços contínuos, em extensos setores de climas quentes, úmidos ou subúmidos, ou subquentes, igualmente úmidos ou subúmidos, com três a cinco meses secos. A amarração principal entre o grande refúgio dos cerrados de cimeira, do Brasil Central, e as condições climáticas, parece perder para os climas tropicais de planaltos, subquentes e semi-úmidos com estação fortemente chuvosa de verão, e três a quatro meses secos, no inverno, sujeitos a precipitações médias anuais, variando entre 1.300 a $1.800 \mathrm{~mm}$, segundo se pode depreender de diversos grupos de dados existentes em um bom estudo do clima regional do centro-oeste, da autoria de Edmond Nimer (1977).

De um modo geral, os cerrados que ocupam depressões interplanálticas, muito mais quentes do que as cimeiras dos platôs - ainda que sujeitos à mesma sazonaridade - ali se instalaram, recentemente, nos últimos milênios, tendo descido dos macrorrefúgios intermediários de cimeira segundo tudo leva a crer. Fato que já se constituiu - se comprovado - num bom ponto de partida para a análise do quadro de condições paleoclimáticas e paleoecológicas que precedem a formação da atual área nuclear dos cerrados do Brasil Central. Tal constatação, entre outras implicações, documentaria que o domínio morfoclimático dos cerrados e cerradões 
tem sua área de máxima tipicidade nos planaltos sedimentares e cristalinos de altitude média, de Goiás e Mato Grosso, muito mais do que propriamente nas combinações regionais de formas de relevo, solos e vegetação das depressões interplanálticas que marginam ou se interpenetram pelo Brasil Central, por nós já aludida. É um tanto ilusório, entretanto, pensarse que os cerrados nasceram e se fixaram sempre em altiplanos refrigerados do Planalto Central, já que tais planaltos ainda no Terciário Inferior possuíam níveis altimétricos relativos, de centenas de metros, abaixo do seu nível atual. O soerguimento das cimeiras mantidas por cargas - tipo planalto de AnápolisBrasília - nos permite deduzir que até o Oligoceno existiam extensas planuras detríticas com lateritas em formação em setores hoje muito soerguidos e transformados em verdadeiros planaltos.

\section{O quadro paleogeográfico de 13.000 - 18.000 anos}

Os documentos que possuimos para caracterizar as condições geoecológicas e paleoclimáticas recentes do Planalto Central são fragmentários e descontínuos. Pouco sabemos das flutuações climáticas, menores ou locais, referentes aos últimos seis ou oito mil anos. E, no entanto, temos informações bem mais seguras referentes às mudanças climáticas mais drásticas, correspondentes à época genética das stone line intertropicais brasileiras, já constatadas e reconhecidas em numerosas áreas do país, e referíveis ao último período de glaciação quaternária (Würm - Wisconsin Superior). Deixando de lado, a análise das flutuações menores e mais localizadas, ocorridas nos últimos milênios (Holoceno), examinaremos o quadro de mudanças mais radicais, que tiveram sua atuação entre os 13.000 e 20.000 anos, aproximadamente. Trata-se de um quadro referencial que interessa ao país inteiro e, até certo pon-ı to de vista, à própria América do Sul, tomada em seu conjunto.

No que tange aos níveis de interesse do quinto simpósio realizado sobre os cerrados, deve-se salientar em relação aos fatos referentes ao último grande período seco do Pleistoceno - expandiu, de modo complexo, no interior dos planaltos inter e subtropicais brasileiros - o que se conhece tem apenas o sabor de uma primeira aproximação ( $A b^{\prime}$ 'Saber, 1977). Trata-se de conhecimentos ecléticos, muito recentemente reunidos, apenas para atingir um esquema de mapa prévio, no interesse de uma visua lização antecipada, e a serviço de futuras completações e melhorias, através da ótica das muitas disciplinas em jogo.

Basicamente, os documentos mais concretos que tornam possível esta primeira aproximação, dizem respeito ao encontro de "linhas de pedra", na estrutura superficial da paisagem. Convém lembrar, porém, que tais indícios de antigos chãos pedregosos tem um valor relativo, pois nada dizem diretamente sobre quais teriam sido os stocks de floras a elas associados em cada setor de ocorrência. No entanto, indicam sempre vegetação esparsa, de troncos finos, ou de cactáceas, onde os fragmentos locais de barras de rochas resistentes, foram capazes de se esparramar no chão das antigas paisagens, vindo a formar chãos pedregosos, de maior ou menor espessura. Para esse atapetamento do chão de paisagem, apenas a gravidade e as enxurradas em lençol devem ter colaborado: os fragmentos, de diferentes natureza petrográfica, origens e formas, percolaram por entre as raízes de uma vegetação raquítica.

Levando-se em conta os patrimônios biológicos, ainda hoje dominantes no espaço ecológico total de nossos planaltos interiores, podemos afiançar que apenas os diferentes facies de caatingas, assim como alguns tipos de cerrados naturalmente degradados, poderiam ter ocupado os antigos chãos pedregosos, hoje soterrados na epiderme das paisagens regionais e reocupados extensivamente por cerrados e cerradões. É de se supor, ainda, que paisagens de cactáceas como aquelas que hoje ocorrem na zona pré-andina da Argentina, desde o norte de San Juan até San Miguel de Tucuman, podem ter penetrado áreas do entorno do Pantanal MatoGrossense e depressões interplanálticas do sul do Brasil, comportando eventuais chãos pedregosos e tornando possível a ocorrência de minienclaves de cactáceas até os dias atuais, vinculados à área dos antigos pedregais, hoje total ou parcialmente soterrados.

Tais documentos sedimentários inclusos nas formações superficiais da região - ou seja, participando da estrutura superficial atual da região dos cerrados - têm muito mais validade, quando associado a outros indicadores paisagísticos, tais como presença de paleoinselbergs, hoje representados por relevos residuais das superfícies interplanálticas regionais. Além do que, quando localizados no mesmo espaço em que aparecem os documentos detríticos mais antigos (também indicativos de climas mais secos do passado), tais como cascalheiras de terraços fluviais, leques aluviais grosseiros e fragmentos de sedimentação interrompidos.

A análise de tais tipos de documentos - centrada na época de predominância das stone lines revelou-nos um pouco das paisagens que antecederam de perto as atuais, por ocasião do último período seco quaternário (Pleistoceno Superior). O quadro obtido é muito preliminar e digno de muitos reparos. No entanto, não nos furtamos de oferecê-los à consideração, análise e crítica de nossos compa- 
nheiros da área biológica, a serviço da interdisciplinaridade.

- o conjunto das paisagens típicas de cerrados, no Planalto Central, era menor e menos contínuo, por ocasião do último período seco;

- todas as depressões interplanálticas que envolvem ou interpenetram o conjunto das terras altas atuais do Planalto Central eram faixas de paisagens fortemente diferentes, comportando muito menos cerrados e mais caatingas, ou vegetações similares;

- nas depressões interplanálticas ocorriam certamente faixas de contato de vegetação, do tipo a que chamaremos de faixas de contato e transição intradomínio morfoclimático dos cerrados;

- predominavam cerrados degradados interfluviais e caatingas de encostas, em diferentes combinações no interior das aludidas depressões interplanálticas;

- nos altiplanos refugiavam-se os cerrados e alguns núcleos de cerradões, sob a forma de "bancos de flora", os quais, mais tarde, quando da umidificação generalizada sofrida pela região em seu todo, serviram para o repovoamento vegetal do domínio dos cerrados, tal como hoje o entendemos em sua área nuclear. Foi, somente, a partir dessa época, que os cerradões passaram a predominar sobre os facies de cerrados naturalmente degradados, então predominantes;

- possivelmente as caatingas ou vegetações similares estenderam-se até o Médio Vale do São Francisco mineiro, alcançando a região kárstica situada ao norte de Belo Horizonte, assim como o interior das cristas quartzíticas e ferríticas do quadrilátero central do centro-sul de Minas Gerais;

- fora das depressões interplanálticas, algumas áreas, como os próprios chapadões areníticos do Urucuia, tiveram coberturas vegetais de climas mais secos, comportando cerrados degradados ou até mesmo manchas de caatingas;

- em altitude, nas altas encostas de serranias quartzíticas (Espinhaço, Pirineus de Goiás, reverso de altas cuestas areníticas) predominavam campos rupestres desenvolvidos em chãos pedregosos ou solos sub-rochosos, acima do nível do cinturão de cerrados, e à cavaleiro das caatingas das depressões interplanálticas, mais quentes e menos arejadas em face dos escassos ventos úmidos da época;

- no vale do Paranã, em plena depressão interplanáltica situada entre o chapadão de Brasília e os chapadões do Urucuia, deve ter predominado caatinga sobre cerrados naturalmente degradados (substandard);

- paisagens e condições ecológicas de caatingas predominaram ao norte dos bordos acidentados da região de Brasília, após as grandes matas do "Mato Grosso de Goiás", outrora mais extenso. Essa área de caatingas, em níveis rebaixados do Planalto Goiano, formavam uma ligação nordeste-sudoeste das regiões secas nordestinas com outras áreas semiáridas do centro-norte e nordeste de Mato Grosso;

- no entorno do grande Pantanal MatoGrossense, sobretudo no Pediplano Cuiabano, desde Rosário Oeste até Santo Antônio do Leverger, ocorriam setores semi-áridos interplanálticos, provavelmente relacionados com a área de vinculação entre a vegetação pré-andina da Argentina ou com faixas de vegetação cactácea das depressões interplanálticas do extremo sul do país, outrora muito mais frias e secas do que as atuais pradarias mistas ou bosques subtropicais regionais;

- no extremo sul de Mato Grosso, onde hoje existe os campos de vacaria, deveria existir estepes e campos limpos, mais frios e mais secos do que os atuais prados "marginais", ali refugiados. Onde hoje ocorrem as matas de Dourados deveriam ocorrer bosques subtropicais, alternados com campestres, no esquema ainda hoje observável mais para o sul do país (na área de vacaria, no nordeste do Rio Grande do Sul, por exemplo);

- franjas de cerrados ficaram interpostas entre as florestas galerias tropicalizadas e os prados que substituíram estepes ou campos limpos secos, no sul de Mato Grosso. Esquema parecido com o que ocorreu nas serranias das proximidades de Barbacena e Tiradentes, em Minas Gerais, onde as matas tropicais ganharam o fundo dos vales e os cerrados ficaram interpostos entre elas e os campos limpos dos altos das cristas, onde outrora medravam campos rupestres em chão pedregoso;

- um antigo refúgio de matas subtropicais situado no Vale do Paraná lextremo oeste do Paraná, que designamos provisoriamente por Refúgio Foz do Iguaçu) deve ter sido tropicalizado, nos últimos milênios, afogado que foi pelas florestas de climas quentes, reexpandidas a partir de refúgios situados no norte do Paraná e oeste de São Paulo. Conviria fazer um inventário de sua flora para testar esta hipótese, baseada na dinâmica aparente das coberturas florestais, da margem sul do domínio dos cerrados. Por outro lado, convém retirar em definitivo o extremo sul de mato Grosso da área nuclear dos cerrados;

- a grande transversal de formações abertas no Brasil intertropical que vem desde a área das caatingas brasileiras até o Chaco, passando pela área nuclear dos cerrados, foi muito mais "corredor" de formações abertas, no Pleistoceno Superior, do que nos últimos milênios. Isto porque, o espaço nuclear dos cerrados, comportava aquele tempo muito mais 
áreas de cerrados naturalmente degradados, entremeados com caatingas nas depressões interplanálticas (Médio São Francisco mineiro e Paranã, Alto Araguaia) e pequenas estepes secas de altitudes, do que propriamente densos e contínuos cerradões. Os cerradões, ao contrário do que nós próprios pensávamos pertencem a um patrimônio biológico, arcai$\mathrm{co}$, comportando-se como adensamentos de biomassas de cerrados, a nível de verdadeiras florestas, reexpandidas na cimeira de planaltos depois da última grande fase seca pleistocênica (13.000 - 18.000 anos). Tal fato, reforça a idéia básica de que cerradões quando degradados por estensivas ações antrópicas não se refazem facilmente. $E$, na prática, jamais se recompõem. Os cerrados, por seu turno, são muito mais resistentes em face de ações predatórias, nãolesionantes. Que os predadores imedialistas de nosso país, não nos ouçam.

De tais constatações, por fim, resultam algumas diretrizes para o bom uso e a preservação de importantes recursos naturais na área nuclear dos cerrados, ou seja, em regiões, tais como, os chapadões do centro e sul de Mato Grosso, Triângulo Mineiro, sudoeste de Goiás e oeste da Bahia, Maranhão e Piauí.

Até a década de 50 as faixas de maior preferência para uso agrícola no Planalto Central eram as calhas aluviais onde existissem densas matas galerias. As várzeas alongadas e contínuas, dotadas de aiuviões, ricas e designadas regionalmente por pindaíbas - eram a exceção em face do campo geral de vertentes e largos interflúvios ocupados por uma pecuária extensiva. A partir da década de 60 e, sobretudo, ao longo da década de 70, extensas áreas dos interflúvios passaram a ser utilizados para a silvicultura, a rizicultura, plantio de abacaxi e eventuais lavouras nobres (soja, café e trigo). A agricultura comercial, sobretudo a do arroz, atingiu o espaço dos cerrados, deslocando fronteiras agrícolas e viabilizando a economia rural de grandes glebas, até então mal-aproveitados e improdutivas. Urge, agora, porém, defender os patrimônios biológicos, com maior cuidado e grau de racionalidade. Com base no estudo das modificações quartenárias dos componentes paisagísticos regionais, e, sob a ótica do modelo dos refúgios naturais, de floras e faunas, sugerimos três diretrizes básicas para conciliar desenvolvimento e proteção dos patrimônios genéticos:

- a exigir a preservação de percentuais significativos de cerrados e cerradões localizados em abóbadas de interflúvios, transformando-os em verdadeiros bancos genéticos da província fitogeográfica dos cerrados;

- preservação de faixas de cerrados e campestres nas baixas vertentes de chapadões, com dezenas até centenas de metros de largura - segundo cada uso - a fim de que o manejo das terras de culturas não interfiram no equilíbrio frágil da faixa de contato entre vertentes e fundos de vales com florestas galerias;

- congelamento total de uso dos solos das faixas de matas galerias, com vistas à preservação múltipla das faixas aluviais florestadas, assim como, das veredas existentes à sua margem.

Nesse sentido, alertamos aos responsáveis pela preservação dos patrimônios genéticos do país (Secretaria Especial do Meio Ambiente-SEMA, Instituto Brasileiro de Desenvolvimento Florestal-IBDF, Ministério do Planejamento) que o não-atendimento da preservação integral das florestas galerias existentes no Planalto Central pode acarretar conseqüências graves para o abastecimento d'água, o ravimento das baixas vertentes e o aprofundamento e dessecamento dos lençóis d'água subsuperficiais na maior parte do domínio dos cerrados. Até mesmo no interior do sítio urbano de Brasília onde tem havido o caos na ocupação dos solos das faixas de matas galerias já se observam lesionamentos graves em conseqüência do progressivo desmatamento da margem natural das florestas galerias, incluindo-se ocorrências de ravinamentos selvagens na faixa de contato entre as baixas vertentes com cerradose as veredas de solos lixiviados e empobrecidos, que margeiam a verdadeira faixa de florestas galerias.

O total de matas de fundo de vales, sob o arranjo clássico de matas galerias é inferior a $1 \%$ no conjunto do 1,8 milhão de quilômetros quadrados da área nuclear dos cerrados. E esse total, irrisório de vegetação florestal intracerrados - incluindo penetrações das florestas do Alto Paraná e do sul da Amazônia, ao longo das cabeceiras de vales do divisor Prata-Amazonas e chapadões do Piauí - Maranhão e oeste da Bahia - deve merecer tantos cuidados como aqueles a serem dedicados à preservação de bancos genéticos da natureza dos cerrados, ora pressionados pela irreversível deriva das fronteiras agrícolas e interiorização do desenvolvimento econômico e social, nos planaltos interiores do Brasil.

No caso dos cerrados propriamente ditos pode-se prever um aproveitamento máximo da ordem de até $30 \%$ do espaço total da área nuclear do domínio, sem grandes prejuízos para a preservação do patrimônio genético da província florística e faunística regional. Essa avaliação prévia equivale a uma somatória de espaços agrários descontínuos, da ordem de 540 mil quilômetros quadrados, ou seja, uma área duas vezes maior do que o território paulista em seu conjunto e quatro vezes maior do que o dos seus espaços agrícolas, efetivamente produtivos. O grande dilema residirá sempre no desenvolvimento das técnicas de seleção dos subespaços efetivamente 
agricultáveis, sem prejuízo da preservação relativa dos patrimônios naturais do "universo dos cerrados e cerradões".

Em relação ao grande domínio morfoclimático e fitogeográfico dos cerrados - em sua área nuclear - propomos aos órgãos de gerenciamento do meio ambiente no Brasil as seguintes diretrizes mínimas:

- face à nova conjuntura de ocupação econômica dos cerrados, por atividades agrícolas importantes - soja, arroz de sequeiro, milho - , tornar obrigatório a preservação de pequenas e médias "reservas" de vegetação original, em fazendas que possuam áreas superiores a 1.000 hectares, independentemente das posturas legais de proteção preexistentes para matas ciliares e eventuais "capões" de matas. Sugere-se que essas "reservas" de fazendas tenham no mínimo $30 \%$ do espaço total das fazendas, devendo preferentemente ser localizadas nos interflúvios de chapadões;

- provisoriamente, ficam interditados para eventual expansão de espaços agrários, todas as áreas dotadas de verdadeiros cerradões (cerrados regionalmente designados por "cerrados a três pê(os"), estejam eles localizados em qualquer posição na topografia: interflúvios, vertentes altas ou vertentes baixas. Para se liberar trechos de solos de cerradões para fins de ampliação de áreas agrícolas, ou outros quaisquer usos, será necessário exame in situ por equipes técnicas do IBDF, SEMA e Instituto Nacional de Colonização e Reforma Agrária - INCRA. Dado o desaparecimento rápido dos verdadeiros "cerradões", todos os remanescentes dessa vegetação arcaica do Brasil Central, são de interesse para estudos científicos, de ordem botânica e fitogeográfica, assim como, zoológica;

- devem ser protegidas todas as cabeceiras de drenagem existentes no domínio dos cerrados, desde o sul de Mato Grosso até ao Maranhão e Piauí. Campos de cultura em preparo, instalações agrárias, novos espaços incorporáveis ou em vias de incorporação ao mundo urbano não podem interferir nas cabeceiras extremas de cursos d'água, sejam elas de qualquer tipo: cabeceiras em anfiteatros pantanosos com buritis ou caranãs, cabeceiras em bacias de captação dendritificadas. Não devem ser oferecidos incentivos a proprietários ou prefeituras que não tenham sensibilidade em relação à proteção de mananciais;

- levando em conta o encontro de novas fórmulas para o uso econômico rentável dos solos de cerrados nos chapadões do Brasil Central, com rápida expansão da agricultura por largos interflúvios e vertentes - através de dezenas de milhares de quilômetros quadrados - , tornar obrigatório a defesa dos corredores aluviais, dotados de florestas galerias e buritizais. Fazer um alerta para as dificuldades de utilização dos solos das "veredas" e proibir o uso da estreita faixa de transição entre a base da vertente e o início das veredas, onde ocorrem solos fortemente lixiviados, passíveis de erodibilidade intensa (regossolos de base de vertentes em cerrados);

- não se pode eliminar pequenos capões de matas existentes sob a forma de enclave no interior do domínio dos cerrados, situados em glebas públicas ou particulares. Considera-se pequenos capões aqueles de 1 a 20 hectares. Minicapões poderão ser cercados - com uma faixa de 20 metros de cerrados em seu perímetro - para fins de estudos científicos e monitoramento, com base em negociações a serem feitas com os proprietários das glebas. $\mathrm{Au}$ toridades estaduais e municipais ficarão com a tutela da fiscalização dessas pequenas reservas de florestas ilhadas na área nuclear dos cerrados. Estudos científicos e monitoramento das mesma deverão ser feitas pelo IBDF, SEMA, INCRA e Empresa Brasileira de Pesquisa Agropecuária - Embrapa;

- qualquer projeto de colonização dirigido para capões de matas - tipo "Mato Grosso de Goiás" - terá que ser submetido a rigorosa apreciação por parte de instituições mistas elou comissões de especialistas, podendo ser aprovados em bloco, ficar sujeito a modificações internas de diferentes níveis e ordens elou serem proibidos globalmente, por total inadequação. De preferência, todo o entorno desses grandes capões de matas deverá ser preservado, em uma faixa de 100 metros de largura média, do modo mais contínuo possível, como amostra do ecossistema florestal original e baliza do espaço originalmente abrangido;

- fica previsto estudos para delimitação de áreas de topografias ruiniformes típicas para efeitos de criação de parques nacionais, estaduais ou municipais sob controle de visitação. Após a delimitação das áreas mais expressivas de topografias ruiniformes existentes no domínio dos cerrados, em Goiás (Torres do Rio Bonito, Serra da Divisão), Mato Grosso (Planalto dos Alcantilados, altos da Serra do Roncador, Serra Azul, Bodoquema), Maranhão (morros testemunhos e chapadas residuais), e Piauí (Sete Cidades de Piracuruca, chapadas e morros testemunhos de Castelo do Piauí e Pedro II), tomar providências para a organização interna desses parques e elaboração de regulamentos para visitação e desenvolvimento de pesquisas. Em hipótese alguma será possível implantar nessas áreas especiais - dotadas de grande expressão paisagística e feições topográficas bizarras - os equipamentos e esquemas de visitação que foram endereçadas à área de Vila Velha, no Paraná. Pelo contrário, o exemplo de Vila Velha será tomado como sendo o antiexemplo, a fim 
de preservar corretamente os componentes físicos e bióticos da natureza regional;

- impedir o uso dos solos nas frentes de escarpas estruturais, recobertas por cerrados ou matas orográficas, em todo o Brasil Central. Visa-se com isso obter um tipo em acréscimo de áreas refúgios de cerrados. E, eventualmente, preservar matas estabelecidas na frente de escarpas de cuestas, onde qualquer desmatamento seria irreversível;

- dar um tratamento especial à proteção da região kárstica do Brasil Central (Serra da Bodoquema, sobretudo) e elaborar um documento integrado para a defesa da região do Pantanal;

- transformar em área de proteção ambiental um setor representativo da Serra do Espinhaço, em Minas Gerais, no qual possa ser visto o zoneamento altitudinal, desde as matas de encostas baixas e grotões (lado oriental), até os cerrados (lado ocidental) e os agrupamentos de ecossistemas da cimeira da Serra, onde predominam campos rupestres (pradarias de altitude);

- realizar estudos para fazer um parque da Serra dos Pirineus, segundo os melhores e mais racionais objetivos incluídos na idéia de "parques nacionais".

\section{Bibliografia seletiva do domínio dos cerrados}

AB'SÁBER, Aziz Nacib. O Planal to dos Parecís, na região de Diamantina (Mato Grosso). São Paulo, Bol. Paul. de Geogr., (17): 63-79, 1957.

- Conhecimentos sobre as flutuações climáticas do Quaternário no Brasil. Bol. da Soc. Bras. de Geol., 6 (1): 41 -8, 1957 (Transcrito com um anexo, In: Campinas, Notícia Geomorfológica, 1: 24-30, abr., 1958.

- Pavimentos detríticos atuais e subatuais das caatingas brasileiras. Campinas, Not/cia Geomorfológica, (4) : 48-9, 1959.

- Revisão dos conhecimentos sobre o horizonte subsuperficial de cascalhos inhumados do Brasil Oriental. Curitiba, Bol. da Univ. do Paraná; Geografia Fisica, (2) jul., 1962.

. Contribuição à Geomorfologia da área dos cerrados. SIMPÓSIO SOBRE O CERRADO, São Paulo, Ed. Universidade de São Paulo, 1963.

As depressões periféricas do Planalto Brasileiro. In: AZEVEDO, Aroldo, Coord. O Brasil, a terra e o homem. São Paulo, Ed. Nacional, 1964. V. 1, cap. 3, p. $181-4$.

- As ilhas de cerrados das bacias de Taubaté, São Paulo e Atibaia. In: I SIMPÓSIO DE ECOLOGIA INTERTROPICAL. Bahia, SBPC, 1970. São Paulo, Cadernos de Ciências da Terra, (6) : 20-4, 1970.

- A organização natural das paisagens inter e subtropicais brasileiras. In: III SIMPÓSIO SOBRE O CER-
RADO, São Paulo, Ed. Universidade de São Paulo/ Ed. Blücher, 1971. p. 1-14.

O domínio morfoclimático semi-árido das caatingas brasileiras. São Paulo, IGEOG, Universidade de São Paulo, Geomorfologia, (43), 1974.

. Espaços ocupados pela expansão dos climas secos na América do Sul, por ocasião dos períodos glaciais quaternários. São Paulo, Universidade de São Paulo, Paleoclimas, (3): 1977.

Os domínios morfoclimáticos na América do Sul; São Paulo, Universidade de São Paulo, Geomorfologia, (52) 1977.

- Limitações dos informes paleoecológicos das linhas de pedras, no Brasil. São José do Rio Preto, Universidade Estadual de São Paulo, Inter-Facies, (1), 1979.

- Os mecanismos da desintegração das paisagens tropicais no pleistoceno; efeitos paleoclimáticos do período Würm-Wisconsin no Brasil. São José do Rio Preto, Universidade do Estado de São Paulo, Inter-Facies, (4), 1979.

- Dominios morfoclimáticos atuais e quaternários na região dos cerrados. São José do Rio Preto, Universidade do Estado de São Paulo, Craton \& Intracraton, $14,1980$.

Razões da retomada parcial de semi-aridês holocênica, por ocasião do otimum climaticum; primeiras idéias. São José do Rio Preto, Universidade do Estado de São Paulo. Inter-Facies, (8), 1980.

. \& COSTA, Jr., M. Contribuição ao estudo do Sudoeste Goiano. São Paulo, Bol. Paul. de Geogr., (4): 3-26, 1950, Anais da Associação dos Geógrafos Brasileiros, São Paulo, 1953. V. 1, p. 143-217.

ABSY, Maria Lúcia \& VAN DER HAMMEN, T. Some palaecological data from Rondonia, Southern Part of the Amazon Basin. Manaus. Acta Amazônica, 6 (3): 293-9.

A palynological study of holocene sediments in the Amazon Basin; tese de doutorado. Amsterdam, University of Amsterdam, 1979.

ALMEIDA, Fernando Flávio Marques de. Reconhecimento geomórfico nos planaltos divisores das bacias Amazônica e do Prata entre os meridianos 51 ? e 56 ? Wg. Rio de Janeiro, Rev. Bras. de Geogr. 10 (3):397-440, 1949.

ALVIM, Paulo de Tarso \& ARAÜJO, W. A. Soil as an ecological factor in the development of vegetation in the Central Plateau of Brazil. In: INTERNATIONAL GRASSLAND CONGRESS, 6.PROCEEDINGS. Washington, 1953. V. 1, p. 610-6.

- Teoria sobre a formação dos campos cerrados. Rev. Bras. de Geogr. Rio de Janeiro, 16 (4): 496-8, 1954.

AUBRÉVILLE, André. Les lisières forêt-savane des régions tropicales. Paris, Adansonia, N.S., 6 (2): 175-87, 1966.

AZEVEDO, Aroldo de. et alii. Brasil, a terra e o homem; as bases físicas. São Paulo, Companhia Editora Nacional, 1968. V. 1. 
AZEVEDO, Luiz Guimarães de. Vegetação; região leste. In: Atlas do Brasil (Geral e Regional). Rio de Janeiro, IBGE/CNG. 1960.

. Tipos eco-fisionômicos da vegetação da região de Januária - MG. In: II SIMPÓSIO SOBRE O CERRADO. Anais da Acad. Bras. de Ciências. Rio de Janeiro, 1966 . V. 38, Supl. p. 39-57.

BARBOSA, Octávio. Geomorfologia do Território do Rio Branco. Resumo de Conferência. Campinas, Notícia Geomorfológica, (1): 16-8, abr., 1958.

BEARD, J.S. Brazilian Campo Cerrado; fire climax or edaphic climax? Geogr. Review, (39): 664-66, 1949.

. The savanna vegetation of northern, Tropical America. Durram, Duke University Press, Ecological Monograph, 23 (2): 149-215, 1953.

BENNEMA, J. The red and yellow soils of the tropical and sub-tropical uplands. Soils Sciences, 95: 250-57, 1963.

- Caracterfsticas químicas e físicas de latossolos sob vegetação do cerrado. In: Recuperação do Cerrado, 1964. p. 137-44.

BIGARELLA, João José. Variações climáticas no quaternário e suas implicações no revestimento florístico do Paraná. Curitiba, Bol. Paranaense de Geografia, $(10-15): 211-31,1964$

BRANCO, Jaime J. R. Observações sobre a geologia da área de cerrado. In: Recuperação do Cerrado, 1964. p. 93-102.

BRAUN, E. H. G. \& RAMOS, R.R. de. Estudo agrogeologico dos campos Puciari; Humaitá, Estado do Amazo nas e Território Federal de Rondônia. Rev. Bras. de Geografia, 21 (4): 443-97, 1959.

BROWN JR., K.S. \& AB'SÁBER, Aziz N. Ice-age forest refuges and evolution in the neotropics: correlation of paleoclimalogical, geomorphological and pedological data with modern biological endemism. São Paulo, Universidade de São Paulo, Paleoclimas, (5), 1979.

CAILLEUX, André. La ligne des cailloux à la base de sols jaunes. Berlim, Zeitschrift für Geomorphologie, 1 (3): 312, 1957.

Os depositos detríticos, a linha de cascalhos enterrados e os cupins. Campinas. Notícia Geomorfolo. gica, 6 (12) p. 43-49, 1966.

. \& TRICART, J. Zones phytogeographiques et morphoclimatiques du quaternaire, au Brésil. Paris, C. $R$. Soc. Biogeogr., 88 a 93: 7-13, 1957.

CAMARGO, Ångelo Paes de. Clima do Cerrado. In: SIMPO. SIO SOBRE O CERRADO. São Paulo, Ed. Universidade de São Paulo, p. 93-115. 1963.

CAMP. John R. Os extensos campos cerrados do Brasil. Washington, OEA, Américas, 15 (8): 11-4, 1963.

CAMPOS, Gonzaga de. Mappa florestal. Rio de Janeiro, Ministério da Agricultura Indústria e Comércio, 1912.

CHEBATAROFF, Jorge. EI problema de los campos en las regiones tropicales. In: XVIII CONGRÉS INTER-
NATIONAL DE GEOGRAPHIE. Actes du Congrès. Rio de Janeiro, V. G.I/CNB, 1956. p. 299-301.

CHRISTOFOLETTI, Antônio. Considerações a propósito da Geografia Física dos Cerrados. Campinas, Pontifí. cia Universidade Católica, Not/cia Geomorfológica, 6 (11): 5-32, 1966.

CLIMAP, Project Members. The surface of the ice-age earth. Science, 191: 1131-7, 1976.

COLE, Mônica Mary. A Savana brasileira. Rio de Janeiro, Bol. Car. de Geogr. $11(1-2): 5-53,1958$.

COSTA, Manoel Teixeira da. Estructura geológica dos cerrados. In: Recuperação do Cerrado, 1964. p. 83-92.

COUTINHO, Leopoldo M. Contribuição ao conhecimento do papel ecológico das queimadas na floração de es. pécie do cerrado. São Paulo, Universidade de São Paulo, 1976.

COUTO, Carlos de Paula. O pleistoceno Sul-americano e as migrações humanas pré-históricas. In: Pré-História Brasileira. São Paulo, Instituto de Pré-História da USP. V. Especial (XIX Reunião Anual da SBPC), 1968 , p. $3-42$.

CUNHA, F. L de S. \& GUIMARÃES, M. L. Posição Geológica do homem de Lagoa Santa no Grande Abrigo da Lapa Vermelha Emperaire, Pedro Leopoldo, Estado de Minas Gerais. São Paulo, 1978. Coleção do Museu Paulista, Série Ensaios. v. 2, p. 275-305.

DAMUTH \& FAIRBRIDGE. Equatorial deep-sea Askosic Sands and ice-age Aridity in Tropical South America. Geol. Soc. of Amer., Bull., 81: 189-206, jan., 1970.

DENEVAN, William M. Observations on savanna/forest boundaries in Tropical America. SYMPOSIUM ON THE ECOLOGY OF THE SAVANNA-FOREST BOUNDARY. Caracas, 1964.

. The campo cerrado vegetation of Central Brasil. Geogr. Review, 55: 112-15, 1965.

DONSELAAR, Jan Van. An ecological and phytogeographic study of northern Surinan savannas. In: The vegetation of Suriname. Amsterdam, Lanjouw \& Versteegh van Eedefonds/Paramaribo, S'Lands, Bosbeheer, 1965.

Observations on savanna vegetation, types in the Guianas. The Hague, Dr. W. Junk N. V. Publis. Vege tatio, Acta Geobotanica, $17(1-16): 217-312,1969$.

EDEN, Michel J. The savanna ecosystem; northern Rupununi, British Guiana. Montreal, McGill University, Savana Research Project, 1964.

Paleoclimatic influences and the development of savanna in southern Venezuela. Journal of Biogeo-
graphy, 1: 95-109, 1974 .

EITEN, George. An outline of the vegetation of South America. SYMPOSIUM INTERN. PRIMAT. SOC. 1973.

FERRI, Mário Guimarães. Contribuição ao conhecimento da ecologia do cerrado e da caatinga. Bol. da Fac. Filos. Ciênc. e Letr. - USP, (195) -Botânica, (12):
1-170, 1955 . 
ed. Coord. SIMPOSIO SOBRE O CERRADO. São

Paulo, Ed. Universidade de São Paulo, 1963.

. III SIMPÓSIO SOBRE O CERRADO. São Paulo, Ed. Blücher/Ed. Universidade de São Paulo, 1971.

Sobre a origem, a manutenção e a transformação dos cerrados; tipos de savanas do Brasil. Portugal. Ren. de Biologia, $9(1-4)$ : 1-13, 1973.

Sobre a origem, a manutenção e a transformação dos cerrados; Associação Argentina de Ecologia, Ecologia, 1, (1): 5-10, 1973.

FEUR, R. An exploratory investigation of the soils and the agricultural potential of the soil of the future federal district in the central plateau of Brazil; tese. Cornell University, 1956.

FITTKAU, E. J. et alii. Biogeography and ecology in South America. The Hague. Dr. W. Junk N.V. Publs, 1968, V. 1.

- Biogeography and ecology in South America. The Hague. Dr. W. Junk N. V. Publs. 1969, V. 2.

FUSON, Robert $\mathrm{H}$. The origin and nature of american savannas. Oklahoma, Natu. Council for Geogr. Educ. Series, 2. 1963.

GATES, W. L. Modelling the ice-age climate. Science, 191: $1138-44,1976$.

GOODLAND, Robert J. A. A phytosociological study of the northern Rupunini savanna, British Guiana; tese. Montreal, McGill University, 1964.

- The savanna controversy; back ground information of the Brazilian cerrado vegetation. Savanna Research Serie, 15. McGill University, 1970.

- Plants of the cerrado vegetation of South-Central Brazil; tese. McGill University, Botany Dept. Montreal, 1970.

The cerrado ecosystem of Brazil. Paris, UNESCO, 1975.

. \& IRWIN, H. S. Amazonian and cerrado; development and environmental conservation. In: Extinction is forever. New York. New York Botanical Garden, 1977, p. 214-33.

- Amazonian forest and cerrado; development and environmental conservation. In: Extinction is forever. New York, New York Botanical Garden, 1977, p. 214-33.

- \& FERRI, M. G. Ecologia do cerrado. São Paulo, Ed. Itatiaia/EDUSP, 1979.

HAFFER, Jürgen. Speciation in Amazonian Forest birds; most species probably originated in forest refuges during dry climatic periods. Washington, AAAS, Science, (3889): 131-7, 1969.

HARDY, F. Senile soils. 9th Ann. Carib. Conf. Univ. of Florida. Gainesville, p. 14-43.

—. Edaphic savannas. II CA. Turrialba, 1960.

HESTER, J. J. Late pleistocene environment and early man in South America; Arizona, Temple. The American Naturalist, 100 (914): 377-88, 1966.

HOEHNE, Frederico Carlos. Fitofisionomia do Estado de Mato Grosso e ligeiras notas a respeito da composi. cão e distribuição da sua flora. São Paulo, Cia. MeIhoramentos, 1923.

HUBER, Otto. Le savane neotropicali. Ist. Italo-Latino Americano con la col. Dell'ist Bot. dell'Univ. di Ro$\mathrm{ma}, 1974$.

HUECK, Jurt. Sobre a origem dos campos cerrados no Brasil e algumas novas observações no seu limite meridional. Rio de Janeiro, Rev. Bras. de Geogr. 19 (01): $67-82,1957$

Die Wălder Sudamerikas. Ukologie, Zusamensetzung und Witschafttliche Bedeutung, Stuttgart, Gustav Fischer Verlag, 1966.

As florestas da América do Sul. Trad. de Die Wulder Südamerikas, por Hans Reichardt, Brasília - Ed. da Univ. de Brasflia/São Paulo, Ed. PolígonoS.A., 1966.

\& SEIBERT, P. Vegetationskarte von Südamerika. Mapa de Vegetación de América del Sur. Stuttgart. Gustav Fischer Verlag, 1972.

KUHLMANN, Edgard. Os tipos de vegetação; grande Região Centro-Oeste. Rio de Janeiro, IBGE, 1960.

. Vegetação; Centro-Oeste. In: At/as do Brasil; geral e regional, Rio de Janeiro, IBGE/CNG, 1960. p. 437. 48.

LIMA, Dárdano de A. Contribuição à dinâmica da flora do Brasil. Recife, Universidade de Recife, Arquivos do ICT (Instituto de Ciências da Terra), (2): 15-20, out. 1946.

LINDMAN, C. A. M. A vegetação de Mato Grosso. In: A/bum Graphico do Estado de Matto Grosso. Corumbá, Hamburg, 1914. p. 295-306.

LISBOA, Miguel Ribeiro Arrojado. Oeste de São Paulo, sul de Mato Grosso. EF. Noroeste do Brasil, Rio de Janeiro, Com. E Schnoor. Tip. Jornal do Comércio, 1909.

LOEFGREN, Alberto. Contribuição para a botânica paulista; região campestre. Memória das excursões botânicas de 1887, 1888 e 1889. Bol. da Com. Geogr. e Geol. do Estado de São Paulo, 1890.

MAACK, Reinhard. Geologia e geografia física da bacia hidrográfica do Rio de Contas no Estado da Bahia. Curitiba, Bol. do Inst. de Geol. da Univ. do Paraná, Geografia Fisica, 5. 1963.

MAGNANINI, Alceo. Origem e distribuição do cerrado da caatinga e do pantanal no Brasil. Rio de Janeiro. Bol. Car. de Geogr. 13, (3/4): 83-6, 1960.

McCONNELL, R. B. Planation surfaces in Guyana. London, The Geographical Journal, 134 (4): 506-20, 1968.

MOMSEN JR, Richard P. The forest-frassland boundary between Jaraguá, Anápolis and Goiânia on the Central Plateau of Brazil. XVIII CONGRES INTERNA. TIONAL DE GEOGRAPHIE. Rio de Janeiro, 1965 , V. 3, p. $82-9$ 
MONOD, Theodore. A propos des "campos cerrados". Bull. de I.F.A.N., 12 (3): 844-9, 1950.

MONTEIRO, Carlos Augusto de Figueiredo. Notas para o estudo do clima do Centro-Oeste brasileiro. Rio de Janeiro, Rev. Brasileira de Geografia, 13 (1): 3-46, 1951.

MORALES, Pedro Roa. EI llano central de Venezuela fue un desierto; res. Reunion Tecnica Investigs. BIOLOGIA TROPICS AM. INS. Y CONF., 8. Programa 2CA Tropicos. Maracaibo, 1972.

- Genesis y evolución de los medanos en los llanos centrales de Venezuela. Testemonio de un clima desertico. Caracas, Acta Biologica Venezolana. 10 (1): 19-49.

- Algunos aspectos de la evolución sedimentologica y geomorfologica de la llanura aluvial de desborde en el Bajo Llano. Caracas, Bol. Dela Sociedad Venezolana de Ciencias Naturales, 35 (139): 31-48, 1980.

MULLER, Paul. Vertebratenfaunen brasilianischer Inseln as Indikatore für glaziale und postglaziale Vegetationsfluk Tuazianem. Leipzig. Verhand. der Zool. Gesellschaft, Zool. Anz., Supl. (33): 97-107, 1970.

MYERS, J. G. Savanna and forest vegetation of the interior Guyana plateau. Journal of Ecology, (24): 162-84, 1936.

NIMER, Edmond. Clima; Região Centro-Oeste. In: Geografia do Brasil. Rio de Janeiro, IBGE, 1977.

PAFFEN, Karl Hernz. Das problem der "cerrados" in the Tropen. XVIII CONGRES INTERNATIONAL DE GEOGRAPHIE. Actes du Congrès, 1. Rio de Janeiro, VGI-CNB. 1956 , p. 345-7.

PINTO, M. M. et alii. As geotemperaturas de Brasília e sua correlação com os balanços hídrico e energético. ANAIS DA II REUNIÃO BRASILEIRA DOS CERRADOS. Dep. Nac. de Pesq. Exp. Agropec. Min. da Agric. 1971. p. 180-93.

RAWITSCHER, F. K. et alii. O problema das savanas brasileiras e das savanas em geral. Anuário Brasileiro de Economia Florestal. Rio de Janeiro, INP, 3 (3): $32-8$, 1950.

- et alii. Profundidade dos solos e vegetação em campos cerrados do Brasil meridional. Anais Acad. Bras. de Ciências, 15, 267-94, 1943.

REIS, A. C. de S. Climatologia dos cerrados. In: III SIMPOSIO SOBRE O CERRADO. São Paulo, Ed. da Universidade de São Paulo/Ed. Blücher, 1971, p. 15-26.

RIZZINI, Carlos T. A flora do cerrado; análise florística das savanas centrais. In: SIMPOSIO SOBRE O CERRADO. São Paulo, Ed. da Universidade de São Paulo, 1963.

Sobre as principais unidades de dispersão do cerrado. III SIMPÓSIO DO CERRADO. São Paulo, Ed. Universidade de São Paulo, 1971. p. 117-32.

RODRIGUES, William A. Plantas dos campos do Rio Branco (Território de Roraima). III SIMPÓSIO SOBRE O CERRADO. São Paulo, Ed. da Universidade de São Paulo/Ed. Blücher, 1971, p. 180-93.
RUELLAN, Francis. Alguns aspectos do relevo no Planal to Central do Brasil. Anais da Assoc. dos Geógr. Bras. São Paulo, A. G. B., 1947. V. 2, p. 17-28.

SAMPAIO, A. J. de. A flora de Mato Grosso. Arch. Mus. Nac., Rio de Janeiro, (19): 1-25, 1916.

Fitogeografia do Brasil. 3 ed. São Paulo, Companhia Editora Nacional, 1934.

SANTOS, L. B. et alii. Vegetação; Região Centro-Oeste. In: Geografia do Brasil. Rio de Janeiro, IBGE, 1977.

SARMIENTO, G. The dry plant formation of South American and their floristic connections. Journal of Biogeography, 2: 233-51, 1975.

SERVANT, M. \& VILLARROEL, R. Le problème paleoclimatique des Andes boliviennes et de leurs piedmonts amazoniens au Quaternaire; note. Paris, C. R. Academie des Sciences, 288: 665-8, fev. 1979.

SICK, Helmut. Landschaftsformen in Zentralbrasilien. Frankfurt. Die Umschau in Wissenchaftund Tecknik 55, (17): 529-32, 1955.

SIMPSON - VUILLEUMIER, Beryl. Pleistocene change in the fauna and flora of South America. Science, 173: $771-80,1971$

- Pleistocene Changes in the fauna and flora of South America. Science, 173: 171-80, 1971.

SMITH, Herbert. A região dos campos no Brasil. Rio de Janeiro, Rev. Mensal (Seção da Soc. de Geogr. de Lisboa no Brasil): 48-55, fev. 1885 .

- Do Rio de Janeiro a Cuyabá; notas de um naturalista. Rio de Janeiro, 1886

SMITH, L. B. Origins of the flora of Southern Brazil. Contr. U.S. Nat. Herb. 35: 215-49, 1961.

SOARES, Lúcio de Castro. Limites meridionais e orientais da área de ocorrência da floresta amazônica em território brasileiro. Rio de Janeiro, Rev. Brasileira de Geografia, 15, (1): 3-95, jan./mar. 1953.

TRICART, Jean. Division morphoclimatique du Brésil atlantique central. Rev. de Géomorph. Dynam. 9 (1-2) jan./fev. 1958.

Existence, au Quaternaire, de periodes sèches en Amazonie et dans les régions voisines. Rev. Géomorph. Dynam. 23, p. 145-58, 1974.

VAN DER HAMMEN, Theodor. A palinological study of the Quaternary of British Guiana. Leidse Geol. Me. ded., 1963 , v. 29 , p. $125-80$.

. Changes in the vegetation and climate in the Amazon Basin and surrouding areas during the Pleistocene. Geologie en Mijnboux, 51, 641-3, 1972.

The Pleistocene Changes of vegetation and climate in the Tropical South America. Journal of Biogeography, 1 (1): 3-26, 1975.

VANZOLINI, Paulo Emflio. Zoologia sistemática, geografia e a origem das espécies. São Paulo, Inst. de Geogr. Univ. de São Paulo. Teses e monografias, 3, 1970. 
- Paleoclimates, relief and species multiplication in equatorial forest. In: MEGGERS, B.J. et alii. Tropical forest ecosystems in Africa and South America; a comparative review. Smithsonian Press, 1973.

. \& WI LLIAMS, E.E. South America anoles; the geographic differentiation and evolution of the anolis chrysolepis especies group (Sauria, Iguanidae). São Paulo, Arquivos de Zoologia, 19. 1970.

VEGAS, L. F. \& VEGAS, A. Notas geográficas sobre la Gran Sabana. Caracas Bol. de la Soc. Venez. de Ciências Naturales, 8 (55): 201 -4, 1943.

VELOSO, Henrique Pimenta. Considerações gerais sobre a vegetação do Estado de Mato Grosso: notas preliminares sobre o cerrado. Rio de Janeiro, Departamento de Imprensa Nacional, Memórias do Instituto Oswaldo Cruz, 44 (4): 579-603, 1946.

Considerações gerais sobre a vegetação do Estado de Mato Grosso; notas preliminares sobre o Pantanal e zonas de transição. Rio de Janeiro, Departamento de Imprensa Nacional, Memórias do Instituto Oswaldo Cruz, 45 (1): 253-72; 1947.

Considerações gerais sobre a vegetação do Estado de Goiás; notas preliminares sobre a fitosociologia do Planalto Central brasileiro. Rio de Janeiro, Departamento de Imprensa Nacional, Memórias do Instituto Oswaldo Cruz, 46 (1): 89-124, 1948.

. Fitofisionomia e algumas considerações sobre a vegetação do Centro-Oeste brasileiro. Com. de Ests. Geogrs. da Região Centro-Oeste do Brasil. Rio de Janeiro, Departamento de Imprensa Nacional, Memorias do Instituto Oswaldo Cruz, 46 (4): 813-52, 1948.

- Os grandes clímaces do Brasil; considerações gerais sobre a vegetação do Centro-Oeste. Rio de Janeiro, Departamento de Imprensa Nacional, Memórias do Instituto Oswaldo Cruz, 61 (2): 357-70, 1963.

- Aspectos fito-ecologicos da bacia do alto Rio Paraguai. São Paulo, IGEOG/USP, Biogeografia, 7, 1972.

VOGT, J. \& VICENTE, P. L. Terrains d'alteration et de recouvrement en Zone intertropicale. Bull. du Bureau de Recherches Geologiques et Minières, (4): 2 -111, 1966.
WARMING, E. \& FERRI, M. G. Lagoa Santa e a vegetação de cerrados brasileiros. São Paulo, Universidade de São Paulo/Belo Horizonte, Ed. Itatiaia, 1973.

WIJMSTRA, T. A. \& VAN DER HAMMAN, T. Palynological data on the history of tropical Savanas in Northern South America. Leiden Geolog. Meded., 38 p. 71-83, 1966.

\section{Mapas e Cartas}

CAMPOS, Gonzaga de. Mappa Florestal. Serviço de Geologia e Mineração do Brasil, 1912. Escala: 1:5.000.000.

EITEN, George. Vegetation provinces in Brazil. In: The cerrado vegetation of Brazil. Botanical Review, 38: 204, 1972.

HUECK, K. \& SEIBERT, P. Vegetationskarte von Sudamerica. FITTKAU, E. J. et alii, ed. Biogeography and Ecology in South America 1: 54-81, 1972.

IBGE-CNG. Tipos de vegetação do Brasil. Escala: 1:5.000.000. Rio de Janeiro, 1962.

IBGE-DG. Brasil; Vegetação. Escala: 1:5.000.000. Rio de Janeiro, 1962.

IBGE-SUPREN. Brasil, áreas de cerrados. Escala:1:5.000.000. Rio de Janeiro DEGEO, Serviço de Atlas, 1976.

KUCHLER, A. W. International bibliography vegetation maps; South America. 2 ed. University of Kansas Libraries, 1980. Seção 1.

LIMA, Dárdano de Andrade. Vegetação. In: Atlas do Brasil. Rio de Janeiro, IBGE-CNG, 1966, p. 11.

MARTIUS, Carl Friedrich Philipp. Provinciae florae Brasiliensis; mapa esquemático. 1:64.500.000. In: Die Physiognomie des Pflanzenreiches in Brasilien, München, 1958.

VELOSO, Henrique Pimenta. Tipos de vegetação (Brasil). In: Atlas florestal do Brasil. MA. Conselho Florestal da Federação do Rio de Janeiro, 1966. 


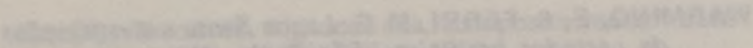

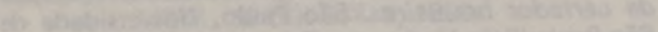

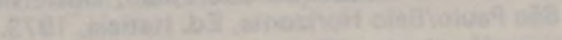

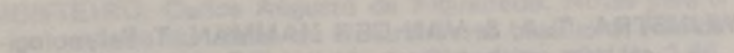

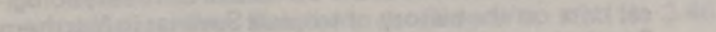

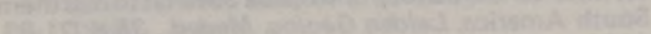
.

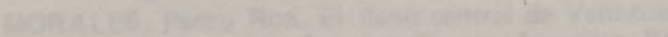

20

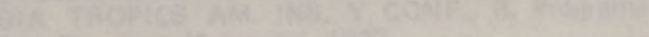

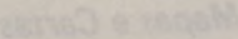

Cont

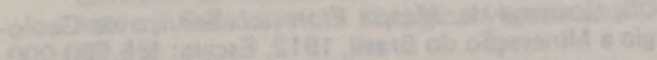

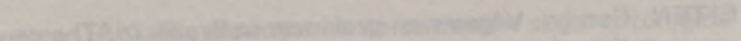
Wach

ㄴ. Thaik

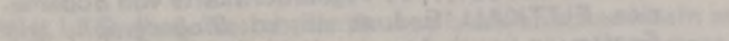

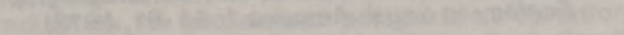

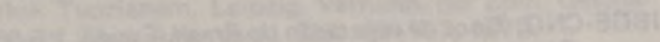

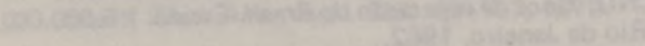

45.

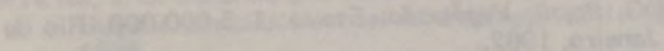

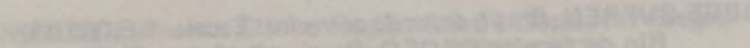

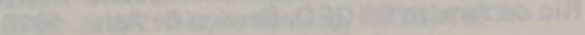

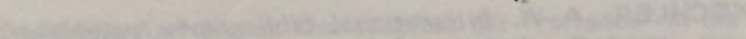

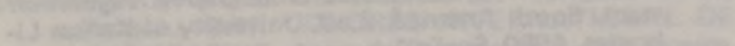

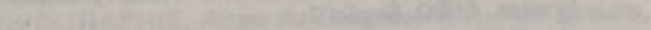

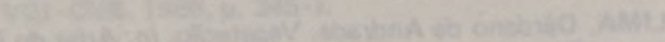

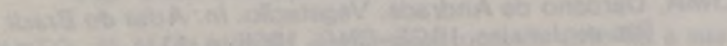

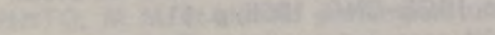

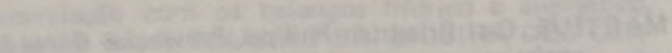

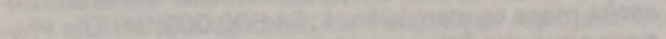

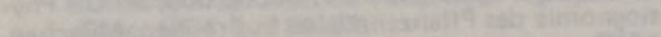

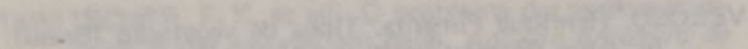

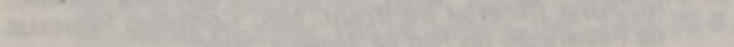

-

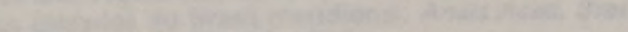
(a)

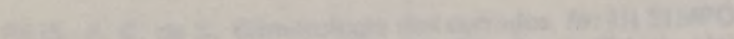

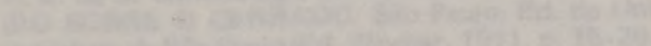

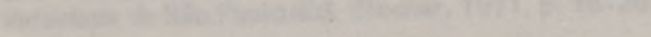

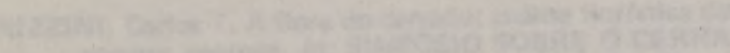

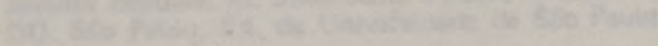

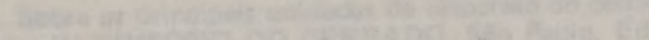

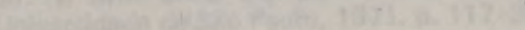

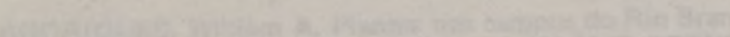

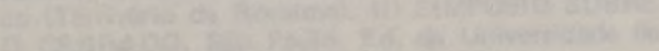

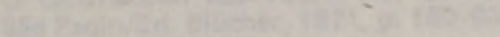

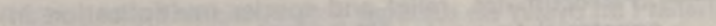

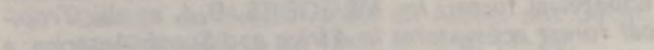

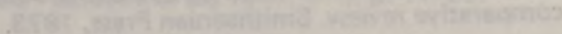

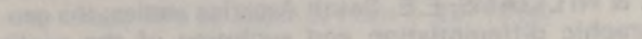

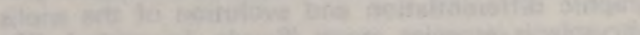

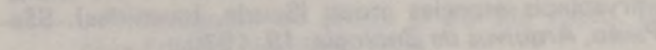

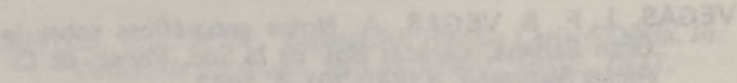

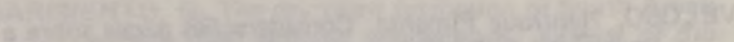

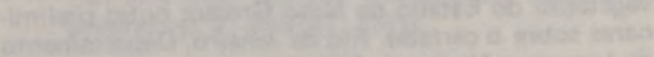

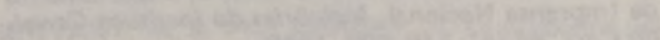

6.

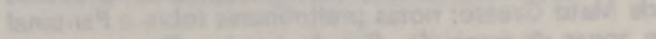

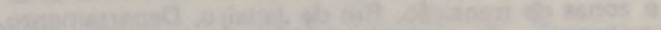

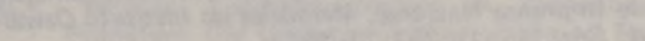

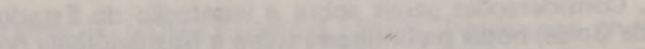

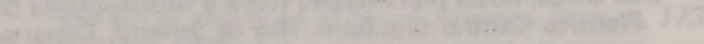

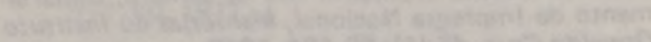

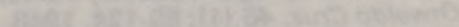

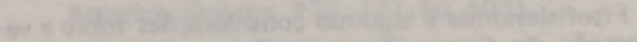

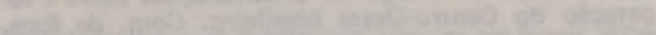

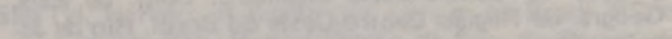

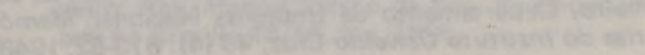

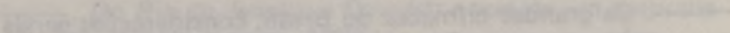
(2. .

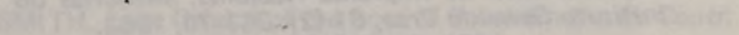

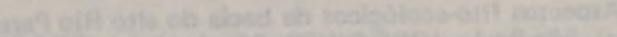

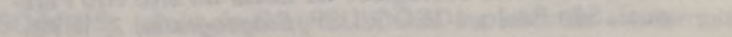

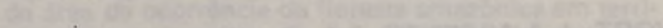

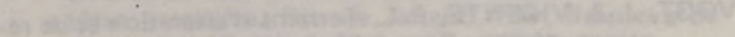

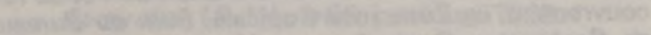
tat.

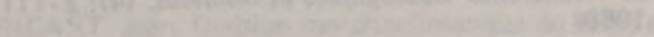

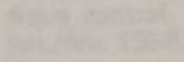

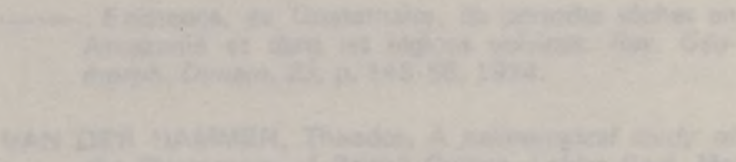

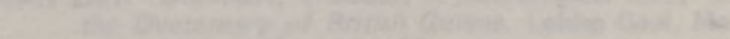
-

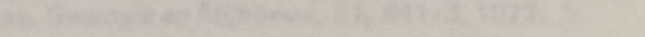

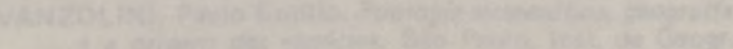

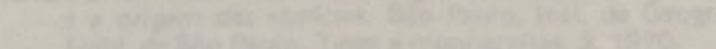

